Highlight

\title{
Ni foam-supported NiCoP nanosheets as bifunctional electrocatalysts for efficient overall water splitting
}

\author{
Xuping Sun *
}

With the energy crisis and global warming, exploration of novel energy sources to replace fossil fuels is a hot topic. $\mathrm{H}_{2}$ is considered as an eco-friendly energy carrier due to its high energy density per unit mass, and when consumed in engines or fuel cells, it produces only water as the byproduct. Conventional approach to $\mathrm{H}_{2}$ synthesis strongly depends on fossil fuels by steam reforming process, leading to serious $\mathrm{CO}_{2}$ emission. Nowadays, an eco-friendly alternative to produce $\mathrm{H}_{2}$ on a large scale is via electrochemical water splitting [1-7]. The overall water splitting reaction consists of two half-reactions: the cathodic hydrogen evolution reaction (HER) and anodic oxygen evolution reaction (OER), both of which require catalysts to improve their efficiency and reduce their overpotentials [8]. Although the state-of-the-art catalysts of $\mathrm{Pt} / \mathrm{C}$ and $\mathrm{IrO}_{2} / \mathrm{RuO}_{2}$ exhibit high performance for HER and OER, their widespread uses are hindered by their scarcity and high cost. Moreover, using a bifunctional HER and OER electrocatalyst has advantages of simplifying the system and lowering the cost. As such, it is highly attractive to design and develop earth-abundant bifunctional water-splitting electrocatalysts.

Transition-metal phosphides are an important class of compounds formed by the alloying of metals and phosphorus, and their good electrical conductivity is of great benefit to enhanced electrochemical performances [9-12]. Recently, Fu's group from Heilongjiang University have prepared NiCoP

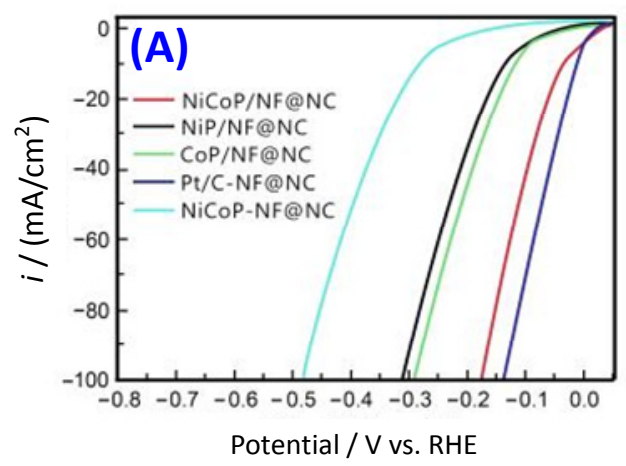

nanosheets grown on $\mathrm{N}$-doped carbon coated $\mathrm{Ni}$ foam (NiCoP/NF@NC) [13]. The linear sweeping voltammetry (LSV) curves show that the NiCoP/NF@NC electrode requires overpotentials of $31.8 \mathrm{mV}$ for the HER and $308.2 \mathrm{mV}$ for the OER to achieve $10 \mathrm{~mA} / \mathrm{cm}^{2}$ in $1.0 \mathrm{M} \mathrm{KOH}$. The HER overpotential is much lower than those for NiP/NF@NC (126.6 mV) and CoP/NF@NC (112.1 mV), demonstrating NiCoP/NF@NC is superior in HER performance to CoP/NF@NC and NiP/NF@NC due to the synergistic effect. Moreover, for the OER catalysis, the overpotential of NiCoP/NF@NC electrode is also lower than those for NiP/NF@NC (349.1 mV) and CoP/NF@NC (383.3 $\mathrm{mV}$ ). Notably, NiCoP/NF@NC has excellent long-term stability without obvious attenuation of performance after 10000 time cycles. Such 3D catalyst electrode has the following advantages for water splitting: (1) it acts as a bifunctional HER and OER electrocatalyst; (2) Ni foam accelerates the diffusion of ions and improve the electrocatalytic performance; (3) introduction of $\mathrm{N}$-doped carbon nanostructures enhances the electrical conductivity and facilitates the transfer rate of electron.

In summary, Ni foam-supported 3D nanostructured NiCoP nanosheets are proven as high-active and durable electrocatalyst for overall water splitting. The whole fabrication process is cost-effective and easy to scale-up. All these remarkable features promise its practical use as an advanced catalyst electrode in water-splitting technological devices.

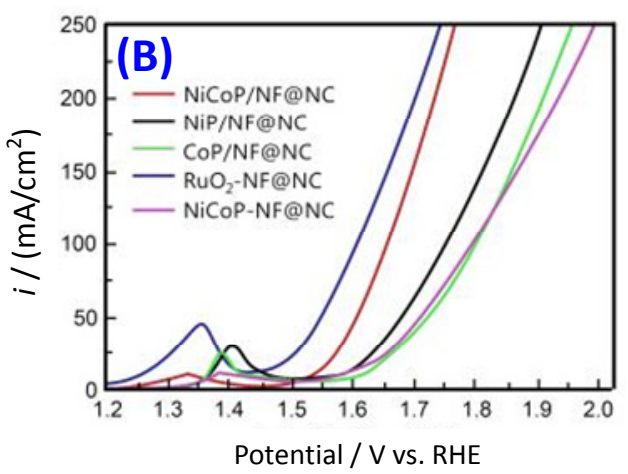

Fig. 1. Linear sweep voltammograms of NiCoP/NF@NC, NiP/NF@NC, CoP/NF@NC, NiCoP-NF@NC and Pt/C-NF@NC in 1.0 M KOH electrolytes with a scan rate of $5 \mathrm{mV} / \mathrm{s}$ for HER (A) and OER (B) processes. 


\title{
Graphical Abstract
}

Chin. J. Catal., 2019, 40: 1405-1407 doi: S1872-2067(19)63443-1

Ni foam-supported NiCoP nanosheets as bifunctional electrocatalysts for efficient overall water splitting

Xuping Sun *

University of Electronic Science and Technology of China

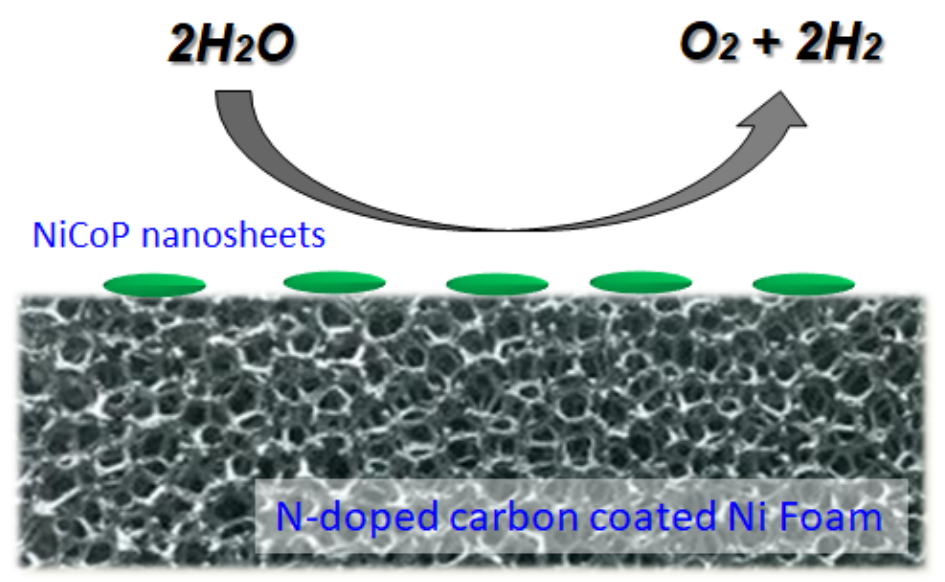

$\mathrm{Ni}$ foam-supported NiCoP nanosheet acts as a high-performance bifunctional water-splitting electrocatalyst with excellent long-term stability without obvious attenuation after 10000 time cycles.

Xuping Sun

Institute of Fundamental and Frontier Sciences

University of Electronic Science and Technology of China

Chengdu 610054, Sichuan, China

E-mail: xpsun@uestc.edu.cn

Received 5 August 2019

Accepted 12 August 2019

Published 5 October 2019

DOI: S1872-2067(19)63443-1

\section{References}

[1] K. Zeng, D. Zhang, Prog. Energy Combust., 2010, 36, 307-326.

[2] S. Ye, G. Li, Front. Chem. Sci. Eng., 2018, 12, 473-480.

[3] M. Carmo, D. L. Fritz, J. Mergel, D. Stolten, Int. J. Hydrogen Energy, 2013, 38, 4901-4934.

[4] M. Pi, X. Wang, D. Zhang, S. Wang, S. Chen, Front. Chem. Sci. Eng., 2018, 12, 425-432.
[5] R. Xiang, C. Tong, Y. Wang, L. Peng, Y. Nie, L. Li, X. Huang, Z. Wei, Chin. J. Catal., 2018, 39, 1736-1745.

[6] Y. Zhang, J. Xiao, Q. Lv, S. Wang, Front. Chem. Sci. Eng., 2018, 12, 494-508.

[7] W. Xie, Z. Li, M. Shao, M. Wei, Front. Chem. Sci. Eng., 2018, 12, 537-554.

[8] C. Tang, N. Cheng, Z. Pu, W. Xing, X. Sun, Angew. Chem. Int. Ed., 2015, 54, 9351-9355.

[9] S. T. Oyama, T. Gott, H. Zhao, Y.-K. Lee, Catal. Today, 2009, 143, 94-107.

[10] J. Tian, Q. Liu, A. M. Asiri, X. Sun, J. Am. Chem. Soc., 2014, 136, 7587-7590.

[11] M. Ledendecker, S. Krick Calderón, C. Papp, H. P. Steinrück, M. Antonietti, M. Shalom, Angew. Chem. Int. Ed., 2015, 54, 12361-12365.

[12] T. Liu, L. Xie, J. Yang, R. Kong, G. Du, A. M. Asiri, X. Sun, L. Chen, ChemElectroChem, 2017, 4, 1840-1845.

[13] M. Tong, L. Wang, P. Yu, X. Liu, H. Fu, Front. Chem. Sci. Eng., 2018, $12,417-424$

\section{泡沫镍担载NiCoP纳米片用作高效双功能水分解电催化剂}

\author{
孙旭平* \\ 电子科技大学基础与前沿研究院，四川成都610054
}

摘要: 随着能源危机和全球变暖, 寻找新能源替代化石燃料成为热门话题. $\mathrm{H}_{2}$ 被认为是环保的能源载体, 因为 $\mathrm{H}_{2}$ 单位质量 的能量密度高, 当 $\mathrm{H}_{2}$ 在发动机和燃料电池中被消耗时, 它只产生水. 传统的 $\mathrm{H}_{2}$ 合成方法主要依靠化石燃料的蒸汽重整, 此 过程会导致大量 $\mathrm{CO}_{2}$ 排放. 目前, 一种大规模生产 $\mathrm{H}_{2}$ 的环保替代方法是电化学水分解. 电化学水分解反应由阴极析氢反应 
(HER)和阳极析氧反应(OER)两个半反应组成, 这两种反应都需要催化剂来提高效率和降低过电位. 尽管 $\mathrm{Pt} / \mathrm{C}$ 和 $\mathrm{IrO} \mathrm{O}_{2} / \mathrm{RuO} \mathrm{O}_{2}$ 催化剂对HER和OER表现出了高性能, 但它们的稀缺性和高成本阻碍了它们的广泛应用. 所以, 使用对HER和OER同时有 效果的双功能电催化剂能够简化系统和降低成本. 因此, 设计和开发地球上丰富的双功能电催化剂具有重要的现实意义.

过渡金属磷化物是金属与磷合金化后形成的一类重要化合物, 其良好的导电性对提高电化学性能具有重要意义. 最 近, 黑龙江大学付宏刚团队制备出了生长在氮掺杂碳包覆 Ni泡沫上的 NiCoP纳米片(NiCoP/NF@NC). 线性扫描伏安(LSV) 曲线显示, 在 $1.0 \mathrm{M} \mathrm{KOH}$ 电解液达到 $10 \mathrm{~mA} / \mathrm{cm}^{2}$ 的电流密度值时, $\mathrm{NiCoP} / \mathrm{NF} @ \mathrm{NC}$ 电极的析氢过电位为 $31.8 \mathrm{mV}$, 析氧过电位 为 $308.2 \mathrm{mV}$, 其过电位远低于 $\mathrm{NiP} / \mathrm{NF} @ \mathrm{NC}(126.6 \mathrm{mV})$ 和 $\mathrm{CoP} / \mathrm{NF} @ \mathrm{NC}(112.1 \mathrm{mV})$, 说明由于双金属的协同效应, $\mathrm{NiCoP} / \mathrm{NF} @ \mathrm{NC}$ 的性能优于 $\mathrm{CoP} / \mathrm{NF} @ \mathrm{NC}$ 和 NiP/NF@NC. 此外, 在 OER 过程, NiCoP/NF@NC电极的析氧过电位也低于 $\mathrm{NiP} / \mathrm{NF} @ \mathrm{NC}(349.1 \mathrm{mV})$ 和 CoP/NF@NC (383.3 mV) 电极. 值得注意的是, NiCoP/NF@ NC 电极具有良好的稳定性, 经过 10000 个循环后, 性能没有明显的衰减. 在电化学水分解反应中, 该催化剂电极具有以下优点: (1)可作为HER和OER双功能 电催化剂; (2)泡沫镍加速离子扩散, 提高电催化性能; (3)氮掺杂碳纳米结构的引入提高了电导率, 促进了电子的传递. 综上 所述, 泡沫镍担载的三维纳米结构 $\mathrm{NiCoP}$ 纳米片被证明是一种高效、耐用的电化学水分解催化剂. 整个制造过程成本效益 高, 易于规模化, 这些显著的特点使其有望作为一种先进的催化剂电极在水分解技术中得到实际应用.

关键词: 氮掺杂碳; $\mathrm{NiCoP}$ 纳米片; 三维纳米结构; 水分解; 电化学

收稿日期: 2019-08-05. 接受日期: 2019-08-22. 出版日期: 2019-10-05.

*通讯联系人. 电子信箱: xpsun@uestc.edu.cn

本文的电子版全文由Elsevier出版社在ScienceDirect上出版(http://www.sciencedirect.com/science/journal/18722067). 